\title{
DESIGN AND EVALUATION OF MOBILE DRIP IRRIGATION SYSTEM
}

\author{
M. F. A. Khairy, ${ }^{(1)}$ A. A. M. Elmesery ${ }^{(2)}$, F. E. Zabady ${ }^{(3)}$, and M. H. Fayed ${ }^{(4)}$
}

\begin{abstract}
Mobile drip irrigation system "MDIS" consists of on/in-line drip hoses at different spaced between lines being dragged through various crops by a center pivot or lateral move irrigation system. Technology of MDIS combines the efficiency of surface drip irrigation (95\%) with the flexibility and economics of center pivot and lateral move irrigation systems. While conventional center pivot and lateral move irrigation water application packages are efficient and provide many different options for distributing water. MDIS technology increased system application efficiency through precision drip irrigation with the slow methodical release of water and nutrients directly to the soil area for optimal plant growth. A mobile drip irrigation system "MDIS" was designed using the classic dripping irrigation materials and determine the best system speed which gives best witting front advance in horizontal, vertical and diagonal directions in the loamy sand soil. The MDIS was evaluated at four system speeds of 5, 10, 15, and $20 \mathrm{~m} / \mathrm{h}$ and three types of drip tubes of $D T_{A}, D T_{B}$, and $D T_{C}$. The results showed that the classification of all used drip tubes were fully pressure compensating and the application efficiency of MDIS was higher than $82 \%$. Also, results obtained the mathematical relationships which describe wetting front advance in horizontal " $H^{\prime \prime}$, vertical " $V$ ", and diagonal " $D$ " directions in loamy sand soil.
\end{abstract}

\footnotetext{
${ }^{(1)}$ Prof., of Ag. power \& machinery, Fac. of Ag. Eng., Al-Azhar Univ., Cairo.

(2) Prof., of Water \& Farm Irrigation Systems, Fac. of Ag. Eng., Al-Azhar Univ., Cairo.

${ }^{(3)}$ Assoc. Prof., of Water \& Farm Irrigation Systems, Fac. of Ag. Eng., Al-Azhar Univ., Cairo.

(4) Assis. Lect., Water \& Farm Irrigation Systems Eng., Dept., Fac. of Ag. Eng., Al-Azhar Univ., Cairo.

(This study is a part of outcomes from Fayed, M. H. "PhD thesis")
} 


\section{INTRODUCTION}

7 rickle irrigation is gaining in importance in the world, especially in areas with limited and expensive water supplies, since it allows

limited resources to be more fully utilized. Replacing the sprinklers on a center pivot "CP" or linear move machine by using polyethylene "P" tubes with emitters to convey irrigation water directly to the soil surface converts a traditional $\mathrm{CP}$ or linear move to a mobile drip irrigation system "MDIS". In stationary drip irrigation, closed plastic tubes with emitters are used to deliver irrigation water to the plants using low pressure. No water losses due to wind drift and spray evaporation occur in sprinkler systems and especially in CP system. The idea of mobile drip irrigation system "MDIS" is a combination of the advantages of stationary drip irrigation with $\mathrm{CP}$ or linear move or boom trailer irrigation systems. The advantages of the stationary drip irrigation are: low operating pressure, low water losses and high irrigation efficiency. The advantages of the CP system are: low capital requirements, flexibility and low labour requirements. In addition, soil cultivation under CP is easy. The operating pressure of the drip tubes can be much lower than that of sprinkler systems. The operating pressure at the inlet of a traditional CP with sprinklers ranges from 400 to $500 \mathrm{kPa}$ as compared with 175 to $225 \mathrm{kPa}$ at the inlet of the MDIS (Hezarjaribi, 2008).

Precision mobile drip irrigation "PMDI" is an irrigation system where drip hoses are attached to a center pivot sprinkler and drug on top of the ground. The placement of water by the hoses on the ground could potentially increase irrigation efficiency over a standard drop nozzle system. In addition, problems associated with wet wheel tracks should be reduced. However, drag hoses lying on the ground could cause more management concerns for farmers. One example would be animal damage to the drip hoses which disrupts uniform water distribution (Olson and Rogers, 2008).

Precision mobile drip irrigation "PMDI" combines the efficiency of surface drip irrigation with the flexibility of center pivot and linear move irrigation systems. While conventional center pivot and linear move irrigation water application packages are efficient and provide many 
different options for distributing water, PMDI technology provides increased system application efficiency through precision drip irrigation with the slow methodical release of water and nutrients directly to the soil area for optimal plant growth.

The PMDI system is an ideal solution for growers to maintain yields even with lower water availability. Crops can be effectively irrigated even with very low $\mathrm{m}^{3} / h$ wells. This technology provides accuracy of water management and greater efficiency than standard pivot nozzling. But best of all, it delivers the most even water pattern/application available. Growers will get all the efficiency of a subsurface drip system at a lower cost per acre versus a conventional center pivot system. Drip has proven, time and again, that it helps growers improve crop quality and yields. Water and nutrients are used more efficiently so input costs are reduced. This results in higher yields up to $20 \%$ yield increases have been recorded over a conventional center pivot system and a uniform, quality crop throughout the entire field (Netafim, 2016).

MDIS technology may develop further and be adopted as an additional irrigation system option in the Great Plains region. However, when combining moving lateral irrigation systems with micro-irrigation technologies, the constraints of both systems must be recognized and addressed (Lamm, 2003).

T-L Irrigation (2016) mentioned that the two main advantages of mobile drip irrigation system "MDIS" are:

1) Overall water efficiency: With the drip line design, eliminate evaporation and wind drift associated with traditional sprinklers because wind will not affect it as it applies the water at a superefficient $95 \%$. MDIS get all the efficiency of surface drip at the much-reduced cost per acre price of center pivots.

2) Dry wheel tracks: In many soils and cropping practices, deep wheel tracks on pivots and laterals are a problem. With MDIS the drip lines water behind the wheels so the tires run on dry ground.

Netafim (2016) said that the advantages of MDIS as bellow: 
1) Potential for $20-30 \%$ water savings.

2) Can be used on either tall or short crops.

3) Significantly reduces evaporation and eliminates wind drift.

4) Reduces and/or eliminates wheel track issues.

5) Soil stays moist without crusting while soil compaction is reduced or eliminated.

6) Increases soil moisture resulting in more water banked into the soil profile.

7) Reduces plugged and frozen nozzles during winter watering.

The main objective of this study was to design of mobile drip irrigation system "MDIS" by using classic dripping irrigation materials and evaluate its performance to manage and control the options for efficient irrigation and various cultivation practices.

\section{MATERIALS AND METHODS}

Experiments were carried out in the experimental field at water and farm irrigation systems engineering department, Faculty of Agricultural Engineering, Al-Azhar University, Nasr City, Cairo, Egypt.

\section{Mobile Drip Irrigation System "MDIS" Components}

The present mobile drip irrigation system "MDIS" designed generally and assembled as shown in Fig. (1). It includes two towers (1) with four driven wheels (175/70R13 82H) (2) for moving the system in linear desired direction. The towers carrying a water supply pipe (3) closed from one end, the other end was connected to water source by two Polyethylene " $P E^{\prime \prime}$ tubes with diameter of $18 \mathrm{~mm}$ (4) by thread adapter $\left(18 \mathrm{~mm} \times 19 \mathrm{~mm}\right.$ male $\left.{ }^{\prime \prime} V^{\prime \prime}\right)$ (5). The water source is generally a water pump (6), fertilizer apparatus (7) and hydraulic equipments as pressure gauge (8), flow meter (9) and pressure regulator (10). The supply pipe includes eight saddles $(63 \mathrm{~mm} \times 12.7 \mathrm{~mm}$ female $)(\mathbf{1 1})$ at spacing of $50 \mathrm{~cm}$, each saddle connected to one end of a vertically oriented drop line assemblies (12) by tavlit push fit elbow male thread $(16 \mathrm{~mm} \times$ 12.7 male) (13). The other end of drop line connected to manual flush valve $(16 \mathrm{~mm})(\mathbf{1 4})$. Each valve connected to the upper end of drip tube $(16 \mathrm{~mm})(\mathbf{1 5})$ and the lower end was closed by line end $(16 \mathrm{~mm})(\mathbf{1 6})$. PCJ on-line drippers (17) installed on the lower end of the drip tube which spaced above the ground. 
MDIS was connected to movement unit at the end of the field by a wire of $6 \mathrm{~mm}$ diameter. This unit includes SEW gearmotor $1 \mathrm{hp}, 60 \mathrm{~Hz}$, 3 phase, and $48 \mathrm{rpm}$. Made in Germany. System speed was varied from 5 to $20 \mathrm{~m} / \mathrm{h}$ by LS inverter, made in Korea, model name is SV008IC5$1 \mathrm{~F}$, single phase, and motor rating is $1 \mathrm{hp}$.

The drip tube was a blind low density polyethylene "LDPE" pipe (outer diameter of $16 \mathrm{~mm}$, internal diameter of $14 \mathrm{~mm}$, and maximum operating pressure of $400 \mathrm{kPa}$ ). A plurality of $\mathrm{PCJ}$, on-line compact pressure compensated drippers was installed on PE pipe. The nominal discharge rate of single dripper was 8,25 , and $40 L / h$ for $D T_{A}, D T_{B}$, and $D T_{C}$ respectively. The number of emitters installed on the drip tubes was calculating based on emitter discharge.

\section{Dimensions in $\mathrm{cm}$}

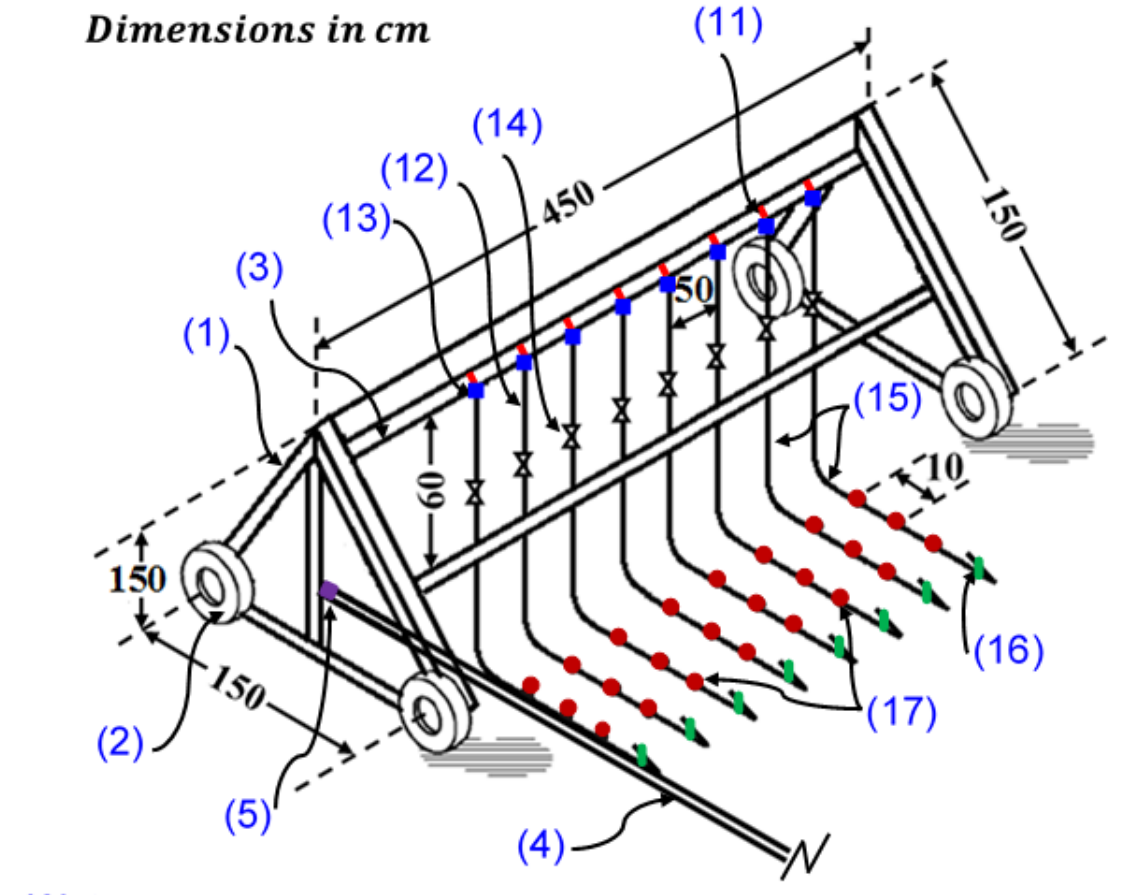

Water

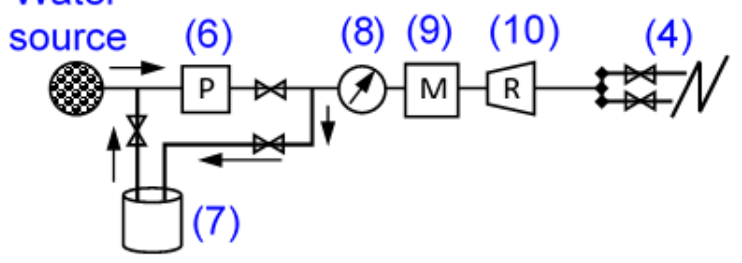

Fig. (1): Mobile drip irrigation system "MDIS". 


\section{Determination Number of Emitters on Drip Tube}

Number of emitter drip tube were calculated as follow:

$$
\begin{array}{r}
\boldsymbol{N}_{e}=\frac{\boldsymbol{q}_{d t}}{\boldsymbol{q}_{e}} \ldots \ldots \ldots \\
\boldsymbol{q}_{d t}=E \boldsymbol{T}_{o} \times \boldsymbol{S} \times \boldsymbol{F} \times \boldsymbol{w} \\
\boldsymbol{E T}_{o}=\boldsymbol{E}_{\text {pan }} \times \boldsymbol{K}_{\text {pan }} \ldots
\end{array}
$$

where $\boldsymbol{N}_{\boldsymbol{e}}$ : Number of emitters on drip tube, $\boldsymbol{q}_{d t}$ : Discharge rate of drip tube, $(L / h), \boldsymbol{q}_{\boldsymbol{e}}$ : Emitter discharge rate, $(L / h), \boldsymbol{E T}_{\boldsymbol{o}}:$ Reference evapotranspiration, $(\mathrm{mm} /$ day $), \boldsymbol{S}$ : MDIS speed, $(\mathrm{m} / \mathrm{h}), \boldsymbol{F}:$ Irrigation frequency, (day), $\boldsymbol{w}$ : Distance between drip tube, $(m), \boldsymbol{K}_{\text {pan }}$ : Pan coefficient "0.55" and $\boldsymbol{E}_{\text {pan }}$ : Pan evaporation ( $\mathrm{mm} /$ day).

\section{Drip tube calibration}

Three types of drip tubes $\left(D T_{A}, D T_{B}\right.$ and $\left.D T_{C}\right)$ were used at four operating pressures $(150,200,250$, and $300 \mathrm{kPa})$. The discharge rate $(L / h)$ of drip tubes were measured by collecting the water dropped from each drip tube in 20 liters container and the time was recorded. Each experiment was repeated three time and the average was calculated.

\subsection{Pressure-Discharge Relationship}

In the design of drip irrigation systems, the relationship between emitter discharge and operating pressure is calculated based on the emitter flow function given by Keller and Karmeli (1974) and Howell et al. (1980) as follows:

$$
\boldsymbol{q}_{\boldsymbol{e}}=\boldsymbol{K}_{\boldsymbol{d}} \cdot \boldsymbol{H}^{x}
$$

where $\boldsymbol{q}_{\boldsymbol{e}}$ : Emitter discharge rate, $(L / h), \boldsymbol{K}_{\boldsymbol{d}}$ : Constant of proportionality that characterizes each emitter, $\boldsymbol{H}$ : The working pressure head at the emitter, $(m)$, and $\boldsymbol{x}$ : Emitter discharge exponent that is characterizes by the flow regime.

\subsection{Manufacturer's Coefficient of Variation ${ }^{\prime \prime} C_{\boldsymbol{v}}{ }^{\prime \prime}$}

Coefficient of variation of the discharge $C_{v}$ is one of the significant parameters related to the uniformity and efficiency of the system. It could be obtained by taking a random sample of drip tubes and measuring the discharge rates at the same temperature and pressure. It was calculated by using the following equation (Lamm et al. 2007):

$$
\boldsymbol{C}_{v}=\boldsymbol{S d} / \boldsymbol{q}_{\boldsymbol{a v g}} \ldots \ldots \ldots
$$


Where $\boldsymbol{C}_{v}$ : Manufacturer's coefficient of variation, $\boldsymbol{S} \boldsymbol{d}:$ Estimated standard deviation of the discharge rates of sampled set of emitters $(L / h)$, and $\boldsymbol{q}_{\text {avg }}$ : The average discharge rates of sampled set of emitters $(L / h)$

The standard deviation values were calculated in the same manner using the following equation (FAO 2002):

$$
S d=\left(\frac{\left(q_{1}{ }^{2}+q_{2}{ }^{2}+\cdots+q_{n}{ }^{2}\right)-n\left(q_{a v g}\right)^{2}}{n-1}\right)^{0.5}
$$

where $\boldsymbol{q}_{1}, \boldsymbol{q}_{2}, \ldots \boldsymbol{q}_{\boldsymbol{n}}$ : Discharge rate of emission devices tested $(L / h)$, and $\boldsymbol{n}$ : Number of emission devices tested.

Classifications of the coefficient of discharge variation values according to ASABE standards (1994).

\subsection{Emission Uniformity " $E U^{\prime \prime}$}

In order to determine whether the system is operating at acceptable efficiency, evaluate the uniformity of emission by calculating emission uniformity by the following equation which suggested by ASAE (1994):

$$
E U=100 \times\left(1.0-\left[\frac{1.27}{\sqrt{n}} C_{v}\right]\right) \times\left(\frac{q_{\text {min }}}{q_{\text {avg }}}\right) \ldots \ldots \ldots(7)
$$

where $\boldsymbol{E} \boldsymbol{U}$ : The design emission uniformity (\%) and $\boldsymbol{q}_{\min }$ : The minimum emitter discharge for minimum pressure in the sub-unit, $(L / h)$.

The evaluated system is classified according to the emission uniformity values obtained, following Merriam and Keller, (1978) and ASABE standards (1999) criterion which is more demanding.

\subsection{Variation from Hydraulic Design " $q_{v a r}$ "}

Flow variation within laterals occur due to pressure head variations and manufacturing variations of the individual emitters. Both of these processes will be discussed and related as to how they can be used in the design process. Lateral emitters flow variation " $q_{v a r}$ " was determined as the following equation given by $\mathbf{W u}$ and Gitlin (1974):

$$
q_{v a r}=\frac{q_{\max }-q_{\min }}{q_{\max }} \times 100
$$


where $\boldsymbol{q}_{\text {var }}$ : Lateral emitters flow variation, $(L / h), \boldsymbol{q}_{\text {max }}$ : The maximum emitter flow rate along the lateral, $(L / h)$, and $\boldsymbol{q}_{\min }$ : The minimum emitter flow rate along the lateral, $(L / h)$.

Wu and Gitlin (1974) recommended the general criteria for emitter flow variation " $q_{\text {var }}$ " values which are $10 \%$ or less is generally desirable, acceptable when between $10 \%$ and $20 \%$, and unacceptable when greater than $20 \%$.

\section{Application Efficiency}

Efficiency of applying water by trickle irrigation depends on the ratio of transpiration to application "$T R^{\prime \prime}$ and the uniformity of application "EU" $E$ (\%). Application efficiency " $\boldsymbol{E}_{\boldsymbol{a}}^{\prime \prime}(\%)$ was calculated by using Keller and Karmeli (1975) equation:

$$
E_{a}=T R \times E U
$$

where value of $T R=0.90$ is a reasonable management expectation.

In this study, three types of drip tubes $\left(D T_{A}, D T_{B}\right.$, and $\left.D T_{C}\right)$ were evaluated at four speeds $(5,10,15$, and $20 \mathrm{~m} / \mathrm{h})$ of linear mobile drip irrigation system (MDIS). Application efficiency of drip tubes $\left(D T_{A}, D T_{B}\right.$, and $\left.D T_{C}\right)$ was calculated at four operating pressures (150, 200, 250, and $300 \mathrm{kPa}$ ). Also, wetting front advance in three directions (Horizontal " $H^{\prime \prime}$, Vertical " $V$ ", and diagonal " $D$ ") was determined in loamy sand soil under three drip tubes $\left(D T_{A}, D T_{B}\right.$, and $\left.D T_{C}\right)$ which used at working pressure of $200 \mathrm{kPa}$ and distances between drip tubes of 100 and $50 \mathrm{~cm}$. PCJ (Pressure compensating junior) on-line compact pressure compensated drippers, were used. Those nominal discharge rates are 0.5, $1.2,2,4,8,25$, and $40 \mathrm{~L} / \mathrm{h}$.

\section{RESULTS AND DISCUSSION}

\section{Calibration Performance of Drip Tubes}

\subsection{Pressure-Discharge Relationships of Drip Tubes}

Fig. (2) illustrate the mean drip tubes discharge rates at different operating pressures for three types of drip tubes which namely $D T_{A}, D T_{B}$, and $D T_{C}$. The pressure-discharge relationships of drip tubes are expressed by equation (4). The values of equation constant " $k_{d}$ " and exponent " $x$ " are listed in Table (1). 
The results showed that all used drip tubes discharge rates were very uniformly distributed at all operating pressures. At the same time, the discharge was relatively the same at all operating pressures because the type of emitters used on drip tubes was a pressure compensating "PC".

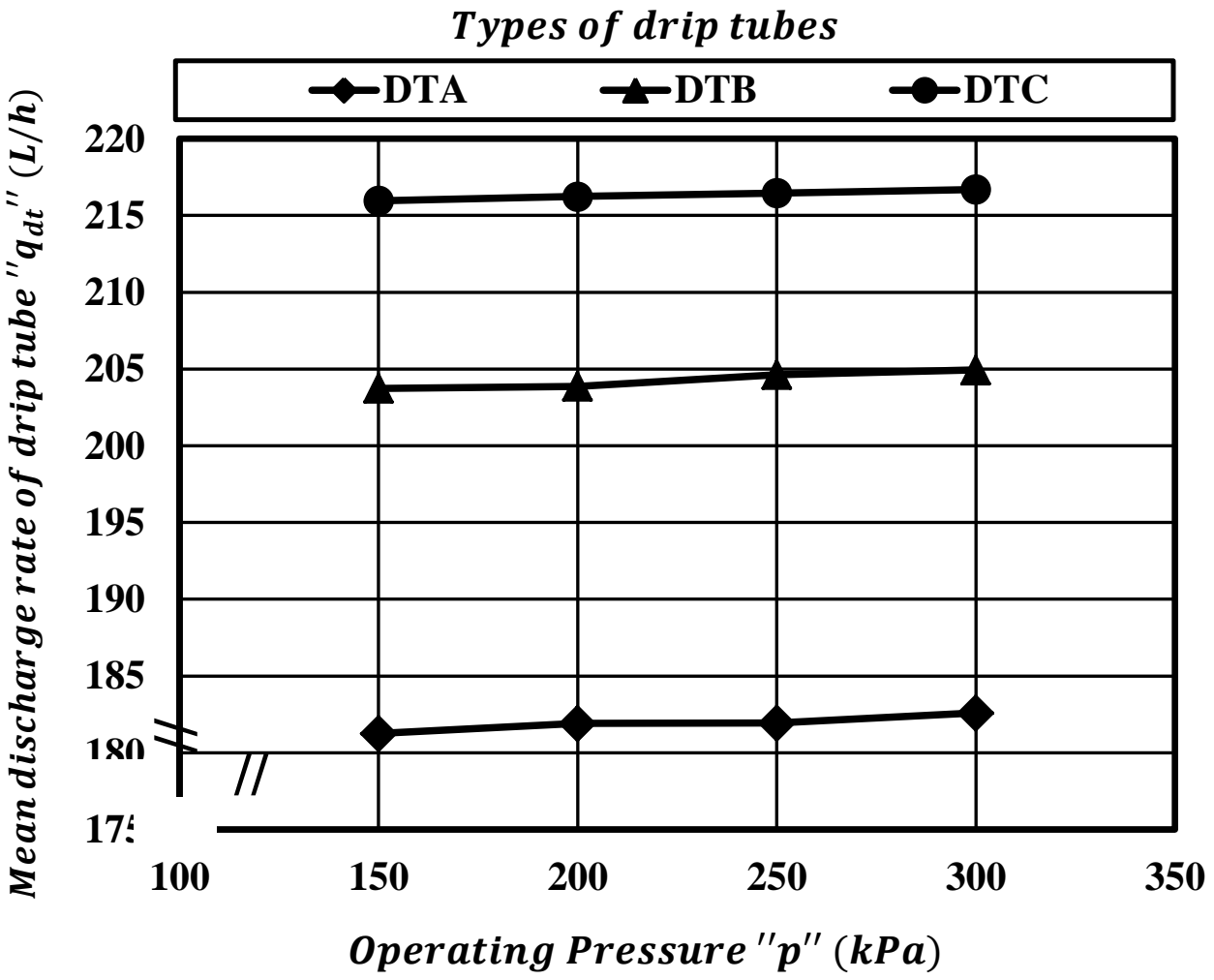

Fig. (2): Relation between mean discharge rate of drip tubes " $q_{d t}^{\prime \prime}$ $(L / h)$ under study and operating pressures " $p^{\prime \prime}(k P a)$.

Table (1): Values of drip tube discharge coefficient ${ }^{\prime \prime} k_{d}{ }^{\prime \prime}$, exponent " $x^{\prime \prime}$, and " $R^{2 "}(\%)$ of tested drip tubes and its classification according to the drip tube discharge exponent values.

\begin{tabular}{lcccc}
\hline $\begin{array}{l}\text { Drip } \\
\text { tube } \\
\text { type }\end{array}$ & $\begin{array}{c}\text { Drip tube } \\
\text { discharge } \\
\text { coefficient } \\
\left(\boldsymbol{k}_{\boldsymbol{d}}\right)\end{array}$ & $\begin{array}{c}\text { Drip tube } \\
\text { discharge } \\
\text { exponent } \\
(\boldsymbol{x})\end{array}$ & $\begin{array}{c}\boldsymbol{R}^{2} \\
(\%)\end{array}$ & Classification \\
\hline $\boldsymbol{D} \boldsymbol{T}_{\boldsymbol{A}}$ & 172.71 & 0.010 & 91 & \\
$\boldsymbol{D} \boldsymbol{T}_{\boldsymbol{B}}$ & 194.60 & 0.009 & 90 & Fully pressure \\
$\boldsymbol{D} \boldsymbol{T}_{\boldsymbol{C}}$ & 210.84 & 0.005 & 99 & compensating \\
\hline
\end{tabular}




\subsection{Manufacturer's Coefficient of Variation " $C_{v}^{\prime \prime}(\%)$ of Drip Tubes}

Fig. (3) shows the relation between the manufacturer's coefficient of variation ${ }^{\prime \prime} C_{v}$ " (\%) and operating pressure " $p^{\prime \prime}(k P a)$ for drip tubes. The results indicated that the coefficient of discharge variation values for all used drip tubes were below 5\%. So, the drip tubes performance was classified on the basis of the coefficient of variation as good according to recommended classification of ASAE Standards (1994).

\subsection{Emission Uniformity "EU" (\%) For Drip Tubes}

Emission uniformity was calculated using equation (7) for drip tubes $\left(D T_{A}, D T_{B}\right.$, and $\left.D T_{C}\right)$ at different operating pressures $(150,200,250$ and $300 \mathrm{kPa}$ ). The relationship between emission uniformity and operating pressure as shown in Fig. (4). The emission uniformity values for drip tubes $\left(D T_{A}, D T_{B}\right.$, and $\left.D T_{C}\right)$ were ranging from 91.46 to $96.28 \%$ at all operating pressures. So, the performance of drip tubes $\left(D T_{A}, D T_{B}\right.$, and $\left.D T_{C}\right)$ was classified on the basis of the emission uniformity as good according to recommended classification of ASABE Standards (1999).

In general, the fluctuation of the coefficient of variation with pressure may be used to define emitter discharge sensitivity to pressure. The manufacturers coefficient of variation should be $15 \%$ or less to achieve reasonable uniformity of water application (Solomon, 1977).

\subsection{Drip Tube Flow Variation " $\boldsymbol{q}_{\text {var }}$ " (\%)}

Flow variation was calculated using equation (8) for drip tubes $\left(D T_{A}, D T_{B}\right.$, and $\left.D T_{C}\right)$ at different operating pressures (150, 200, 250 and $300 \mathrm{kPa}$ ). The relationship between flow variation and operating pressure as shown in Fig. (5). The mean values of flow variation for all types of drip tube are less than $10 \%$. So, all drip tubes were classified on basis of flow variation of drip tube as a desired according to recommended classification of Wu and Gitlin (1974).

\section{Application Efficiency}

Application efficiency was calculated using equation (9) for drip tubes $D T_{A}, D T_{B}$, and $D T_{C}$ at different operating pressures of 150,200, 250 and $300 \mathrm{kPa}$. The relationship between application efficiency and operating pressure is shown in Fig. (6). Application efficiency values for drip tubes 
Types of drip tubes

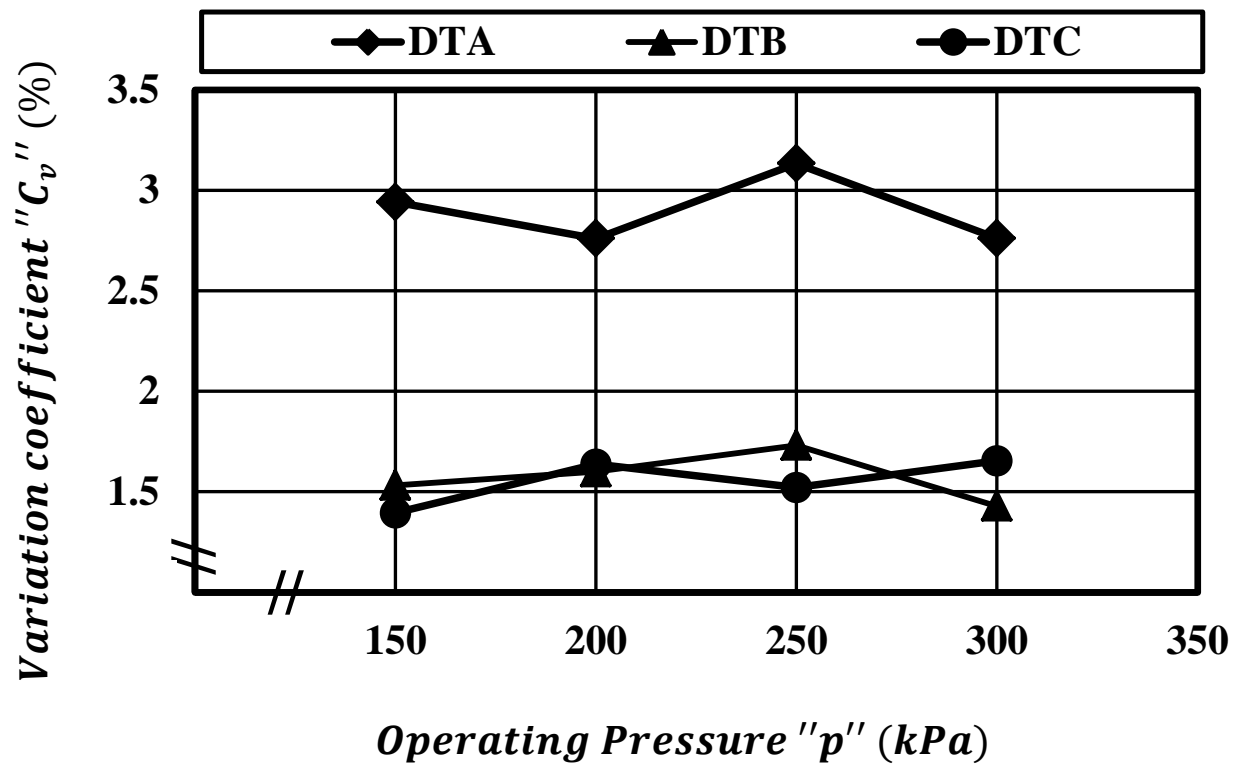

Fig. (3): Relation between the manufacturer's coefficient of variation ${ }^{\prime \prime} C_{v}$ " (\%) and operating pressure " $\boldsymbol{p}^{\prime \prime}(\boldsymbol{k P a})$ for drip tubes under study.

\section{Types of drip tubes}

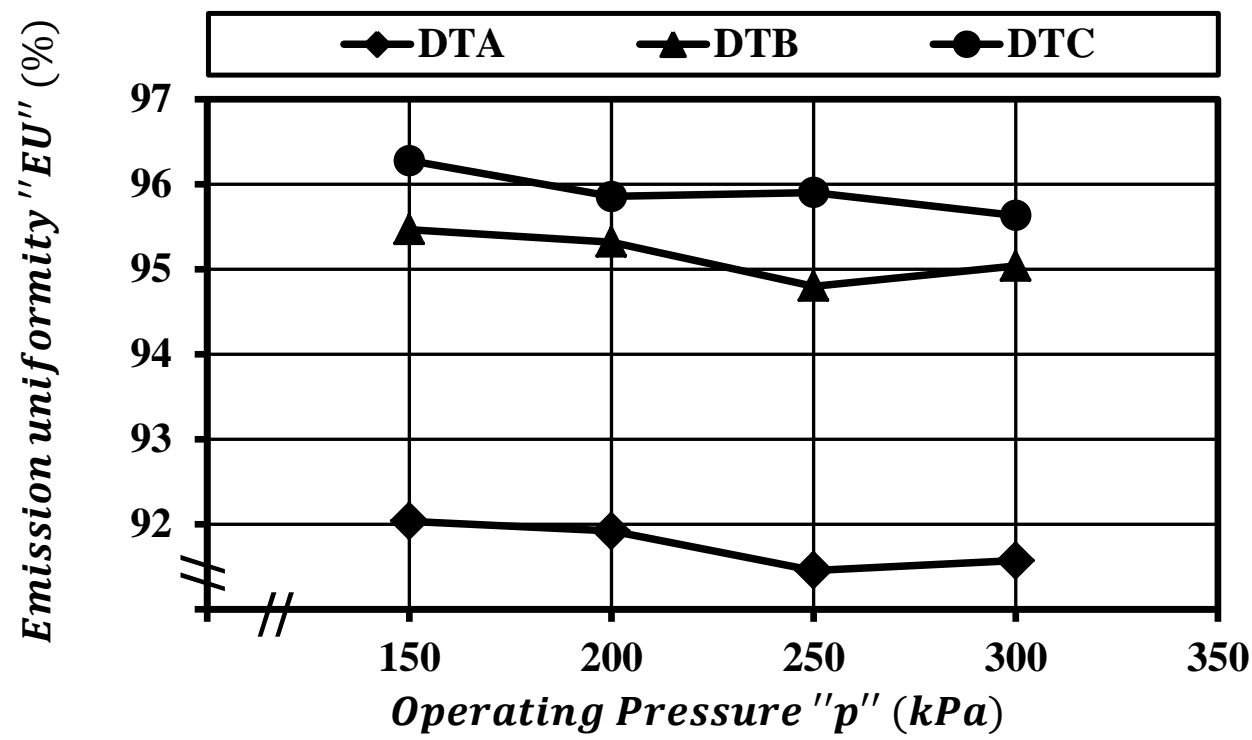

Fig. (4): Relation between emission uniformity "EU" (\%) and operating pressure " $p$ " $(\boldsymbol{k P a})$ for drip tubes under study. 


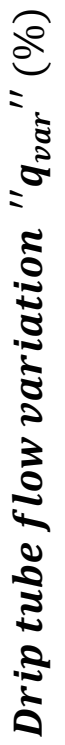

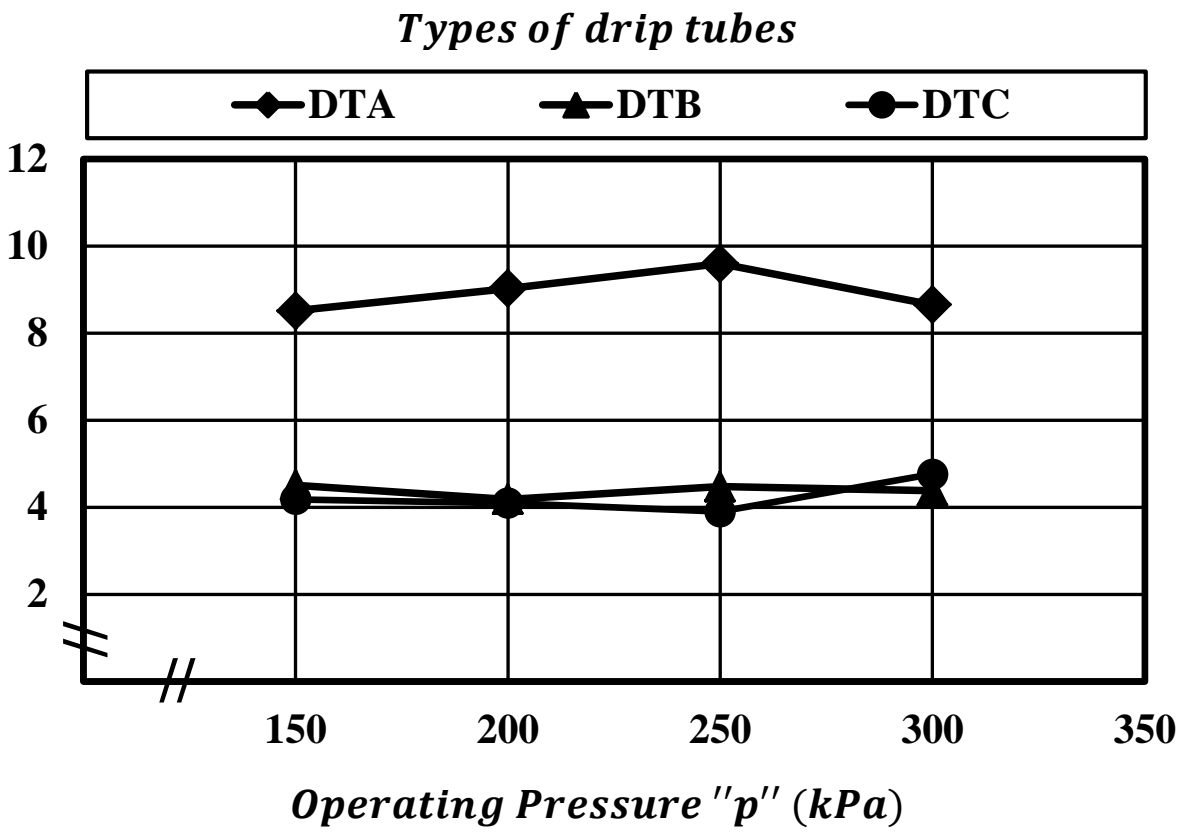

Fig. (5): Relation between drip tube flow variation " $q_{v a r}$ " (\%) at different operating pressures " $p$ " $(k P a)$.

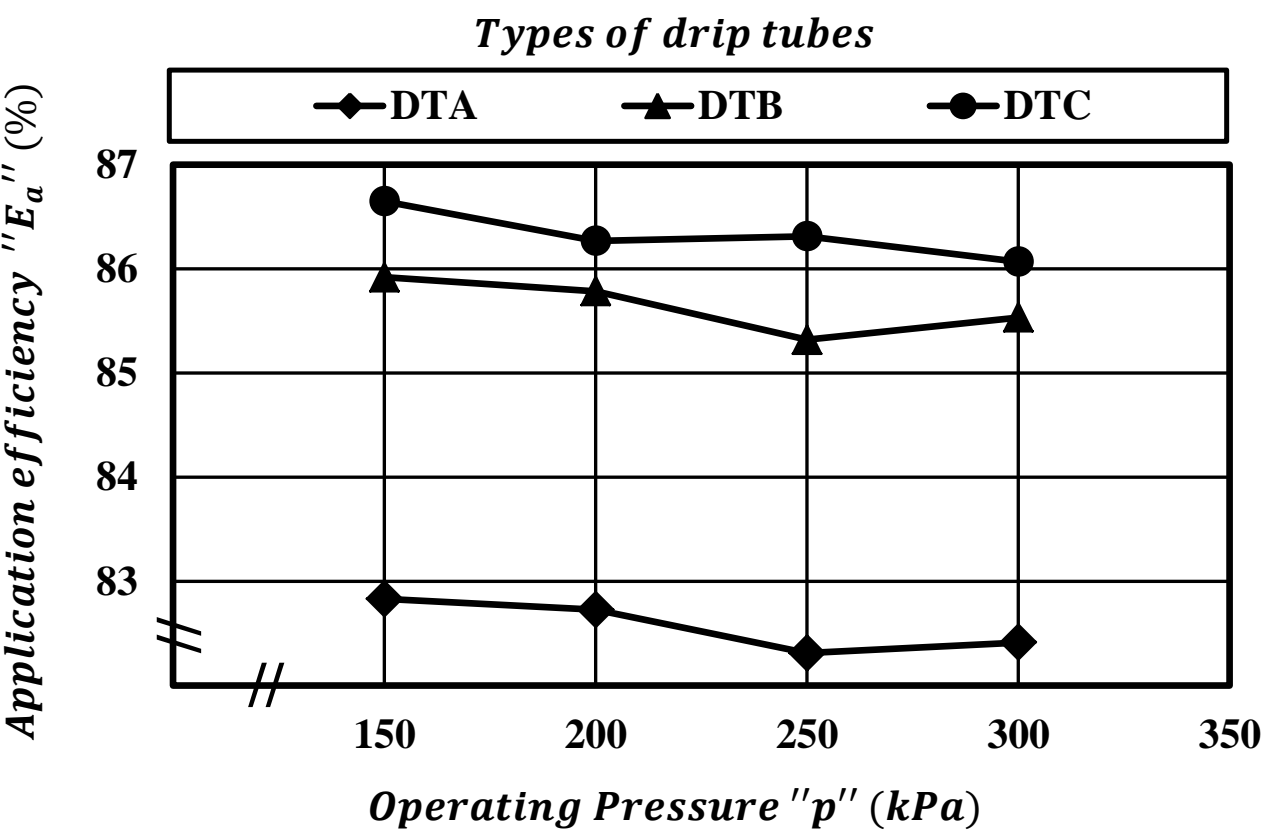

Fig. (6): Relation between drip tube application efficiency ${ }^{\prime \prime} E_{a}{ }^{\prime \prime}(\%)$ at different operating pressures " $p^{\prime \prime}(k P a)$. 
$\left(D T_{A}, D T_{B}\right.$, and $\left.D T_{C}\right)$ were ranging from 82.31 to $82.83 \%, 85.32$ to $85.92 \%$ and 86.07 to $86.65 \%$ respectively at different operating pressures. Generally, application efficiency of drip tubes increases by decrease number of emitter installation on drip tube, therefore number of emitters on drip tube increase by decrease discharge rate of single emitter installation on drip tube.

\section{Wetting Front Advance in Three Directions " $\alpha$ "}

\subsection{Wetting Front Advance at $100 \mathrm{~cm}$ Distance Between Drip Tube}

Fig (7), show the relation between horizontal wetting front advance " $H^{\prime \prime}$, vertical wetting front advance $" V^{\prime \prime}$ and diagonal wetting front advance " $D$ " and speed of mobile drip irrigation system "MDIS" " $\mathrm{S}$ " at different discharge rates of drip tubes " $q_{d t}$ " , different drip tubes $\left(D T_{A} \cdot D T_{B}\right.$ and $\left.D T_{C}\right)$ and $100 \mathrm{~cm}$ distance between drip tubes in loamy sand soil.

From Fig (7), the values of horizontal wetting front advances " $H^{\prime \prime}(\mathrm{cm})$ were increased by increase both discharge rate of drip tube and system speed. Wherever, the values increased from $54.7,58.1$, and $63.7 \mathrm{~cm}$ to 69.5, 70.7, and $70.6 \mathrm{~cm}$, at using $D T_{A} . D T_{B}$ and $D T_{C}$ respectively. Discharge rate of drip tube was ranging from 0.051 to $0.206 \mathrm{~m}^{3} / \mathrm{h}$ when using $D T_{A}$ and $D T_{B}$ types and from 0.045 to $0.218 \mathrm{~m}^{3} / \mathrm{h}$ when using $D T_{C}$. Whereas, system speed was ranging from 5 to $20 \mathrm{~m} / \mathrm{h}$ respectively.

The values of vertical wetting front advances " $V^{\prime \prime}(\mathrm{cm})$ were increased by increase both discharge rate of drip tube and system speed. Wherever, the values increased from $52.7,48.3$, and $51.3 \mathrm{~cm}$ to $63.5,58.6$, and 58.8 $\mathrm{cm}$, at using $D T_{A} \cdot D T_{B}$ and $D T_{C}$ respectively. Discharge rate of drip tube was ranging from 0.051 to $0.206 \mathrm{~m}^{3} / h$ when using $D T_{A}$ and $D T_{B}$ types and from 0.045 to $0.218 \mathrm{~m}^{3} / \mathrm{h}$ when using $D T_{C}$. Whereas, system speed was ranging from 5 to $20 \mathrm{~m} / \mathrm{h}$ respectively.

The values of diagonal wetting front advances " $D^{\prime \prime}(\mathrm{cm})$ were increased by increase both discharge rate of drip tube and system speed. Wherever, the values increased from $49.8,46.2$, and $49.7 \mathrm{~cm}$ to $61.0,56.9$, and 57.0 $\mathrm{cm}$ respectively. Discharge rate of drip tube was ranging from 0.051 to $0.206 \mathrm{~m}^{3} / \mathrm{h}$ when using $D T_{A}$ and $D T_{B}$ types and from 0.045 to 0.218 $\mathrm{m}^{3} / \mathrm{h}$ when using $D T_{C}$. Whereas, system speed was ranging from 5 to 20 $m / h$ respectively. 


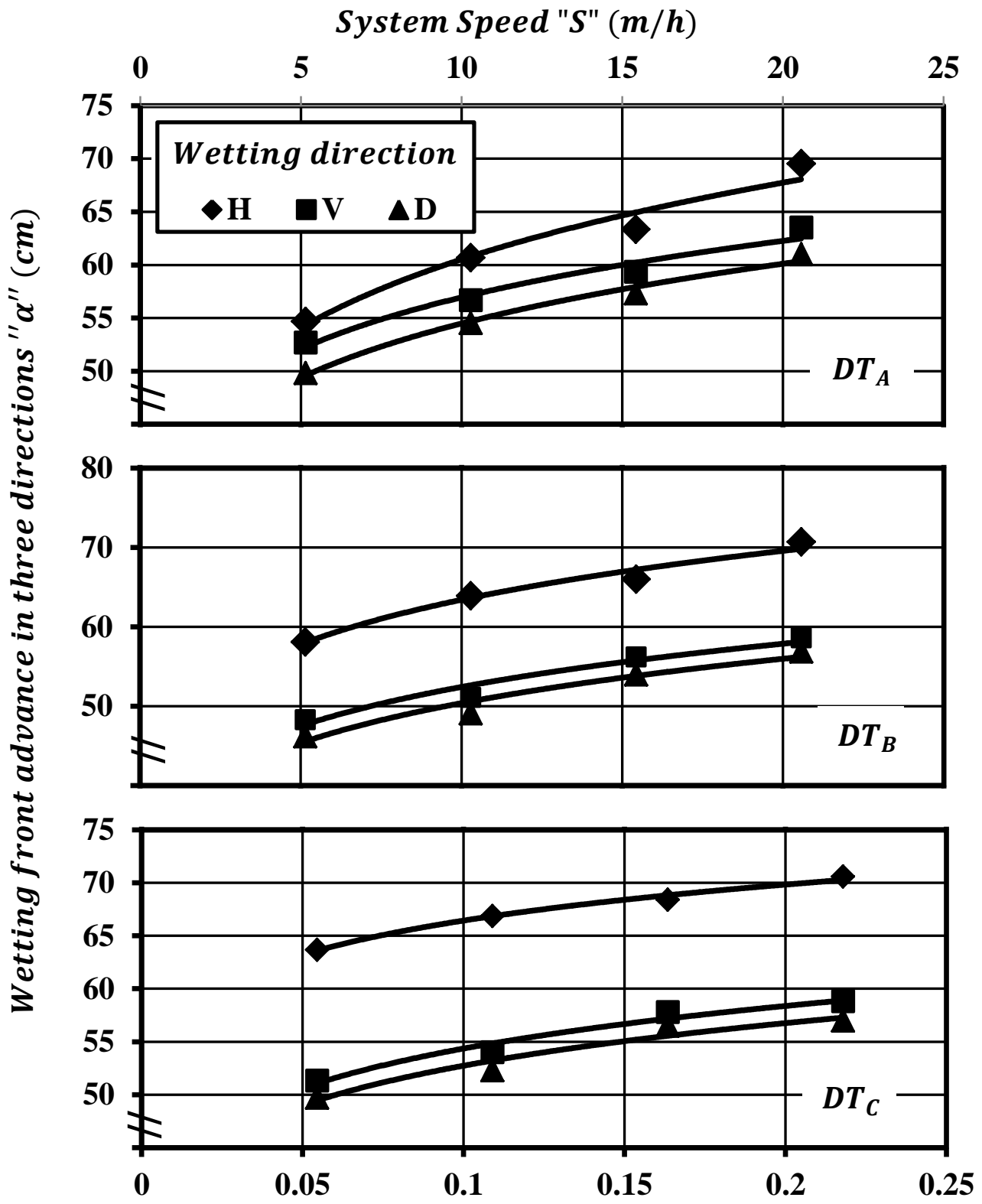

Discharge rate of drip tube $" q_{d t} "\left(m^{3} / h\right)$

Fig. (7): Relation between discharge rate of drip tube " $q_{d t} "\left(m^{3} / h\right)$ and wetting front advance " $H, V$, and $D "(\mathrm{~cm})$ at different drip tubes $\left(D T_{A}, D T_{B}\right.$, and $\left.D T_{C}\right)$ and $100 \mathrm{~cm}$ distance between drip tubes. 
Data showed that, in case of using $D T_{A}$ the wetting front advance in horizontal, vertical, and diagonal directions was relatively equal. Whereas, in case of using $D T_{B}$ and $D T_{C}$ the wetting front advance in horizontal direction was higher than the wetting front advance in vertical and diagonal directions. This results agreement with Goldberg et al., (1971).

Generally, the mean wetting patterns as influenced by the different water application rates and MDIS speed. The horizontal width of wetting was higher than the vertical wetting depth in the highest application rate and MDIS speed treatments. Increasing the application rate and MDIS speed increased the rate of horizontal water advance, while the vertical water advance was markedly reduced as the application rate and MDIS speed increases. This could be attributed to:

(1) The presence of soil surfaces crust, which reduced water infiltration and enhanced the horizontal water movement.

(2) The increased saturated zone at the soil surface due to an increased application rate.

A regression analysis showed that experimental data of the $H . V$. and $D(\mathrm{~cm})$ exposed power functions in relation to discharge rate of drip tube " $q_{d t}$ " $\left(\mathrm{m}^{3} / \mathrm{h}\right)$ or mobile drip irrigation system speed " $S$ " $(\mathrm{m} / \mathrm{h})$ as follows,

$$
\begin{array}{cc}
\text { or } \quad H, V, D=a & H, V, D=a \\
\text { a } & b S^{b}
\end{array}
$$

where $\boldsymbol{H}$ : Width (horizontal) wetting front advance, $(\mathrm{cm}), \boldsymbol{V}:$ Depth (vertical) wetting front advance, $(\mathrm{cm}), \boldsymbol{Z}$ : Diagonal wetting front advance, $(\mathrm{cm}), \boldsymbol{q}_{\boldsymbol{d} t}$ : Discharge rate of drip tube, $\left(\mathrm{m}^{3} / \mathrm{h}\right), \boldsymbol{S}$ : Mobile drip irrigation system speed "MDIS" $(m / h)$, and $\boldsymbol{a}$ and $\boldsymbol{b}$ : Parameters depend on direction of wetting front advance $(H, V$, and $D)$. soil type, and application rate.

The value of $\left(C_{v}\right)$ between values of parameters " $a$ " and " $b$ " was very low $\left(C_{v} \leq 0.02\right)$. Therefore, the mean values of parameters " $a$ " and " $b$ " were listed in Table (2).

$$
\begin{array}{cl}
\text { Generally, } & \alpha=76.146 q_{d t}^{0.127} \\
\text { or } & \alpha=42.859 S^{0.127}
\end{array}
$$

where $\boldsymbol{\alpha}$ : is the wetting front advance in horizontal, vertical or diagonal directions. This results (equation (17)) agreement with Al-Qinna and Abu-Awwad (2001). 
Table (4.2): Values of parameters $a$ and $b$ at the directions of wetting front advance at using different types of drip tubes $\left(D T_{A} . D T_{B}\right.$ and $\left.D T_{C}\right)$ as a function at discharge rate " $q_{d t}$ " of drip tube or a function at system speed " $S$ ".

\begin{tabular}{|c|c|c|c|c|c|c|c|}
\hline \multirow{3}{*}{ Factor } & \multirow{3}{*}{ 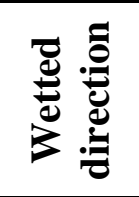 } & \multicolumn{6}{|c|}{ Type of Drip tube } \\
\hline & & \multicolumn{2}{|c|}{$D T_{A}$} & \multicolumn{2}{|c|}{$D T_{B}$} & \multicolumn{2}{|c|}{$D T_{C}$} \\
\hline & & $a$ & $\boldsymbol{b}$ & $a$ & $b$ & $a$ & $b$ \\
\hline \multirow{5}{*}{$q_{d t}$} & $H$ & 88.005 & 0.163 & 86.322 & 0.134 & 78.409 & 0.072 \\
\hline & $\boldsymbol{V}$ & 76.592 & 0.129 & 72.812 & 0.143 & 68.899 & 0.103 \\
\hline & $D$ & 75.501 & 0.142 & 71.456 & 0.152 & 67.314 & 0.106 \\
\hline & $C_{v}$ & 0.09 & 0.12 & 0.11 & 0.06 & 0.08 & 0.20 \\
\hline & Mean & 80.033 & 0.144 & 76.863 & 0.143 & 71.541 & 0.094 \\
\hline \multirow{5}{*}{$S$} & $H$ & 41.816 & 0.163 & 46.784 & 0.134 & 56.641 & 0.072 \\
\hline & $\boldsymbol{V}$ & 42.499 & 0.129 & 37.887 & 0.143 & 43.259 & 0.103 \\
\hline & $D$ & 39.482 & 0.142 & 35.675 & 0.152 & 41.689 & 0.106 \\
\hline & $C_{v}$ & 0.04 & 0.12 & 0.15 & 0.06 & 0.17 & 0.20 \\
\hline & Mean & 41.266 & 0.144 & 40.115 & 0.143 & 47.196 & 0.094 \\
\hline
\end{tabular}

\subsection{Wetting Front Advance at $50 \mathrm{~cm}$ Distance Between Drip Tube}

Fig (8) shows the relation between vertical wetting front advance $(V)$ and speed of mobile drip irrigation system $(S)$ in loamy sand soil at different discharge rates of drip tubes $\left(q_{d t}\right)$, different drip tubes $\left(D T_{A}, D T_{B}\right.$, and $\left.D T_{C}\right)$ and $50 \mathrm{~cm}$ distance between drip tubes in loamy sand soil.

The values of vertical wetting front advances " $V^{\prime \prime}(\mathrm{cm})$ were increased by increase both discharge rate of drip tube and system speed. Wherever, the values increased from 55.5, 50.2, and $48.2 \mathrm{~cm}$ to $63.0,58.7$, and 55.0 $\mathrm{cm}$, at using $D T_{A}, D T_{B}$, and $D T_{C}$ respectively. Discharge rate of drip tube was ranging from 0.027 to $0.109 \mathrm{~m}^{3} / \mathrm{h}$ when using $D T_{A}$ and $D T_{C}$ types and from 0.026 to $0.103 \mathrm{~m}^{3} / \mathrm{h}$ when using $D T_{C}$. Whereas, system speed was ranging from 5 to $20 \mathrm{~m} / \mathrm{h}$ respectively. The deeper wetting front advance was at using $D T_{A}$ at all system speed. The wetting front advance in horizontal $(H)$ and diagonal directions $(D)$ do not measured because of an overlapping in the wet. 


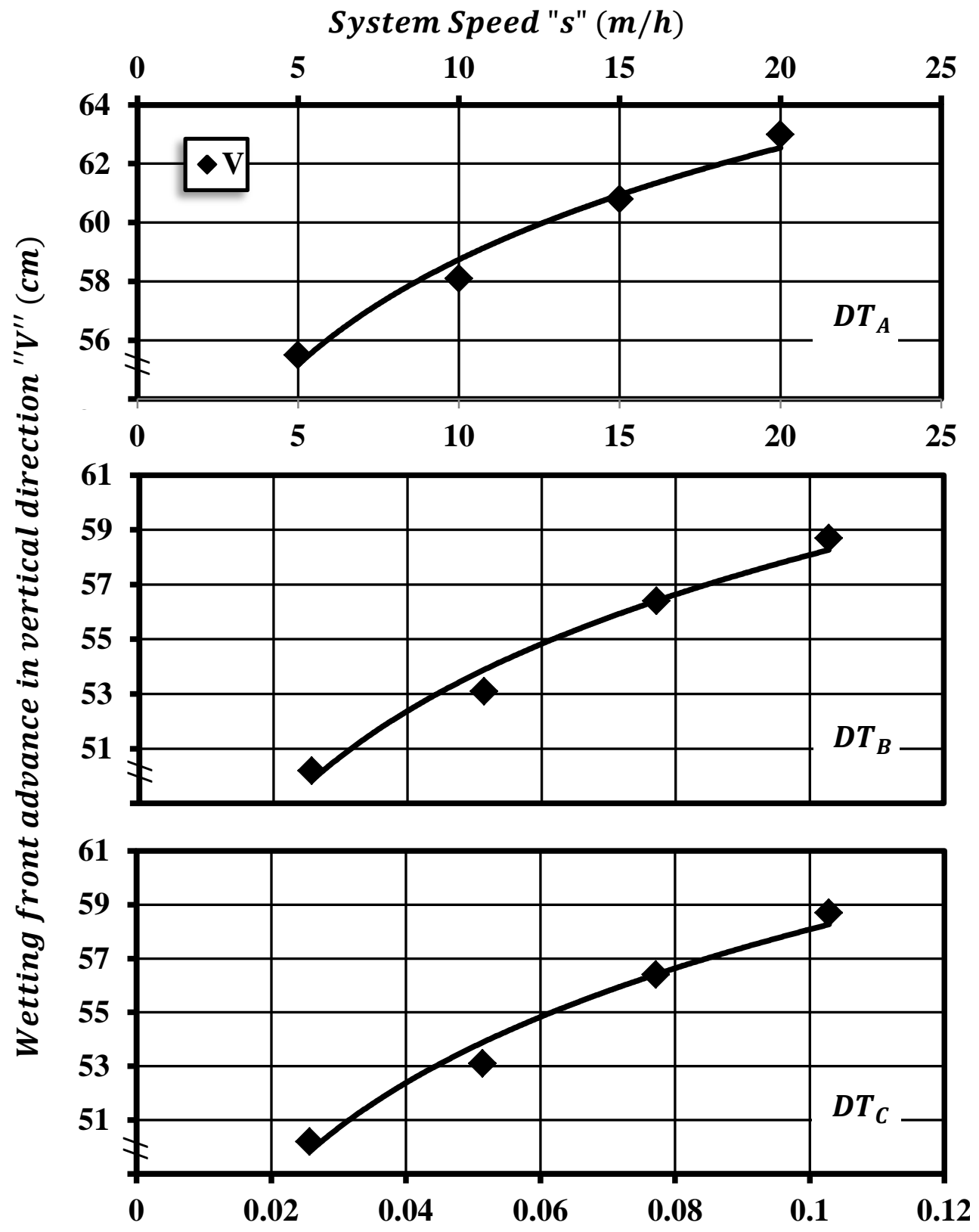

Discharge rate of drip tube $" q_{d t} "\left(m^{3} / h\right)$

Fig. (8): Relation between discharge rate of drip tube $" q_{d t} "\left(m^{3} / h\right)$ and vertical wetting front advance ${ }^{\prime \prime} V(\mathrm{~cm})$ at using different drip tubes $\left(D T_{A}, D T_{B}\right.$, and $\left.D T_{C}\right)$ and $50 \mathrm{~cm}$ distance between drip tubes. 
The values of vertical wetting front advances ${ }^{\prime \prime} V^{\prime \prime}(\mathrm{cm})$ were increased by increase both discharge rate of drip tube and system speed. Wherever, the values increased from 55.5, 50.2, and $48.2 \mathrm{~cm}$ to $63.0,58.7$, and 55.0 $\mathrm{cm}$, at using $D T_{A}, D T_{B}$, and $D T_{C}$ respectively. Discharge rate of drip tube was ranging from 0.027 to $0.109 \mathrm{~m}^{3} / \mathrm{h}$ when using $D T_{A}$ and $D T_{C}$ types and from 0.026 to $0.103 \mathrm{~m}^{3} / h$ when using $D T_{C}$. Whereas, system speed was ranging from 5 to $20 \mathrm{~m} / \mathrm{h}$ respectively. The deeper wetting front advance was at using $D T_{A}$ at all system speed. The wetting front advance in horizontal $(H)$ and diagonal directions $(D)$ do not measured because of an overlapping in the wet.

\section{CONCLUSION}

Technology of mobile drip irrigation system "MDIS" combines the efficiency of surface drip irrigation with the flexibility of center pivot and linear move irrigation systems. Also, MDIS technology provides increased system application efficiency through precision drip irrigation with the slow methodical release of water and nutrients directly to the soil area for optimal plant growth. The main objectives of this study were to investigate the design of mobile drip irrigation system "MDIS" by using classic dripping irrigation materials and evaluate of its performance.

The results of presented drip tubes indicate that the classification of flow regime according to the value of the emitter discharge exponent was fully pressure compensating. the $C_{v}(\%)$ is less than $5 \%$, during all ranges of pressure heads and drip tubes, which classifies them as "good" and within permissible limit. On the basis of $E U(\%)$, all drip tubes performed more than $91 \%$, also in "good class" and shows, that good indicator to reduce the head loss and saving of energy during system operation. The application efficiency of MDIS was higher than $82 \%$.

Also, the results obtained the following equation to describe wetting front advance in horizontal " $H^{\prime \prime}$, vertical ${ }^{\prime \prime} V$, and diagonal ${ }^{\prime \prime} D$ " directions in loamy sand soil:

$$
\begin{array}{r}
\alpha=a q_{d t}{ }^{c} \\
\text { or } \quad \alpha=b S^{c}
\end{array}
$$


Where $\boldsymbol{\alpha}$ : is in any direction $(H, V$, and $D), \boldsymbol{q}_{\boldsymbol{d} t}$ : is discharge rate of drip tube, $\left(\mathrm{m}^{3} / \mathrm{h}\right), \boldsymbol{S}$ : is mobile drip irrigation system speed $(\mathrm{m} / \mathrm{h})$, and $\boldsymbol{a}, \boldsymbol{b}$, and $\boldsymbol{c}$ : are constants depend on type of soil.

\section{REFERENCES}

Al-Qinna, M. I. A. M. Abu-Awwad, 2001. Wetting Patterns under Trickle Source in Arid Soils with Surface Crust. J. agric. Eng. Res., 80(3): 301-305.

ASABE Standards, 1999. EP 458. Field evaluation of microirrigation systems. St. Joseph, Mich.: ASABE. (C.F. Dutta, 2008)

ASAE Standards, 1994. EP405.1. Design and installation of microirrigation systems. St. Joseph, Mich,: ASAE.

Dutta, D. P., 2008. Characterization of drip emitters and computing distribution uniformity in a drip irrigation system at low pressure under uniform land slopes. Master Thesis. Texas A \& M University. Major Subject: Biological \& Agricultural Engineering.

FAO, 2002. Localized irrigation systems; Planning, Design, Operation and maintenance. Developed by Andreas, P., Food and Agriculture Organization of the United Nations, :4(9).

Goldberg, D., B. Gormat and Y. Bar, (1971). The distribution of roots, water and minerals as a result of trickle irrigation. Journal of the American Society for Horticultural Science, 96: 645-648.

Hezarjaribi, A., 2008. Improvement of application map and a dynamic steering of modified centre pivot irrigation system. Ph.D. Thesis Federal Agricultural Research Centre (FAL) Institute of production Engineering and building research BRAUNSCHWEIG - GERMANY.

Howell, T. A., D. S. Stevenson, F. K. Aljibury, H. M. Gitlin, I. P. Wu, A.W. Warrick and P. A. C. Raats, 1980. Design and operation of trickle (Drip) systems. Chap. 16, :663-717. In: Design and operation of farm irrigation systems. M. E. Jensen (ed.), ASAE, 
2950 Niles Road, St. Joseph, Michigan, 49085. (C. F. Phene $\boldsymbol{e t}$ al., 1985)

Keller, J. and D. Karmeli, 1974. Trickle irrigation design parameters. Trans. of the ASAE, 17(4):678-784.

Keller, J. and D. Karmeli, 1975. Trickle Irrigation Design. Rainbird Sprinkler Manufacturing Corporation: Glendora, California, USA; Riverside Printers.

Lamm, F., 2003. Drip irrigation laterals on center pivot irrigation. https://www.ksre.k-state.edu/irrigate/photos/mdi.html

Lamm, F. R., E. A. James, and S. N., Franci, 2007. Microirrigation for Crop Production, Design, Operation, and Management. 1st ed., Copyright 2007 Elsevier B.V.: 1.

Marriam, J. L. and L. Keller, 1978. Farm irrigation system evaluation: A guide for management. Utah State University, Logan, Utah. Dept. of Agricultural \& Irrigation Engineering.

Netafim, 2016. Precision Mobile Drip Irrigation (PMDI) Heavywall Driplines.

http://www.netafimusa.com/agriculture/products/hwdripperline/ p\%D9\%A7/r\%D9\%A7e

Olson, B. L. S. and D. H., Rogers, 2008. Comparing drag hoses verses sprinklers on corn irrigated by a center pivot. Trans. of the ASAE, 24(1):41-45.

Phene, C. J., T. A. Howell and M. D. Sikorski, 1985. A traveling trickle irrigation system. Academic Press, Inc. (London) Ltd. Advances in Irrigation, (3) :1-49. (On line) https://books.google.com.eg/

Solomon, K., 1977. Manufacturing variation of emitters in trickle irrigation systems. ASAE Paper No.77-2009, American Society of Agricultural Engineers, St. Joseph, MI, 49085.

T-L Irrigation, 2016. Precision Mobile Drip Irrigation (PMDI). tlirr.com/products/precision_mobile_drip_irrigation/ 
Wu, I. P. and H. M., Gitlin, 1975. Energy gradient line for drip irrigation laterals. J. Irrig. Drain. Div. ASCE 101 (IR4), 323326.

\section{الملخص العربي}

\section{تصميم وتقييم نظام رى بالتنقيط متحرى}

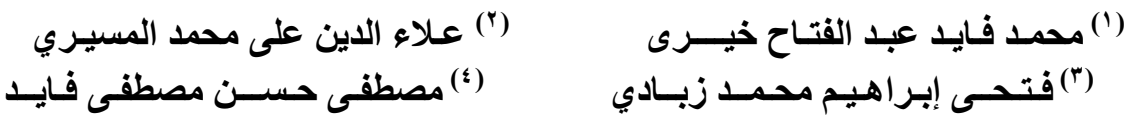

تجمع فكرة نظام الرى بالتنقيط المتحرك بين مزايا نظم الرى بالرش المتحركة والمتمثلة فى في

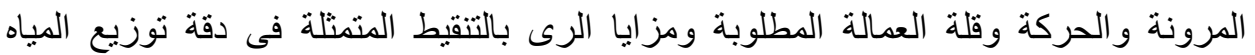

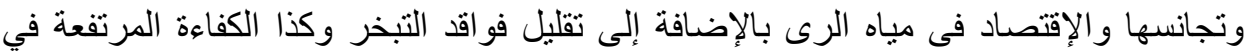
إضافة المياه التي تصل إلى حوالى 90\%

$$
\text { يهدف البحث إلى: }
$$

$$
\text { ( ) تصميم نظام رى بالتنقيط متحرك (يتحرك في خط مستقيم). }
$$

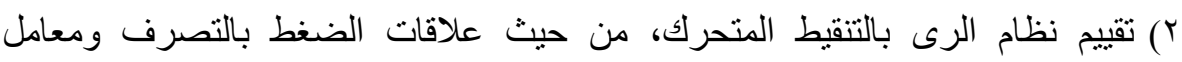

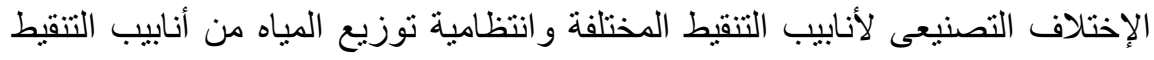

$$
\text { المختلفة وحساب كفاءة إضافة المياه للنظام. }
$$

r) دراسة بعض عو امل التصميم المختلفة مثل سرعة الجهاز و المسافة بين أنابيب التتقيط وكذا الأنواع المختلفة من أنابيب التنقيط.

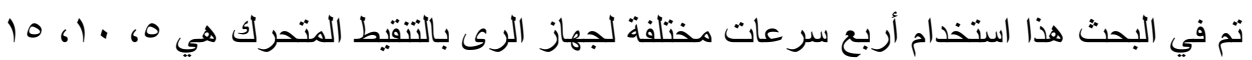

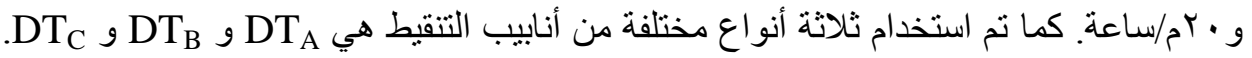

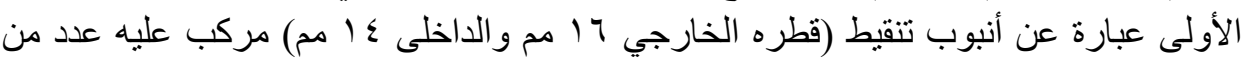

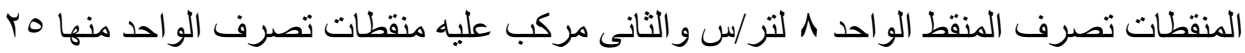

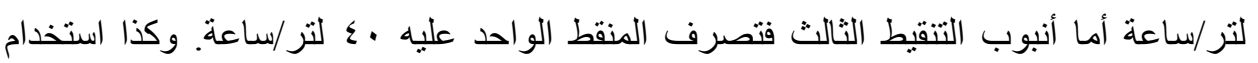

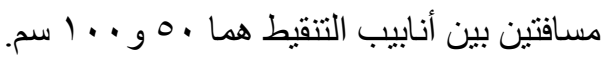
تم قياس تقدم جبهة البلل في الإتجاهات الأفقى و الر أسى و الإتجاه القطرى (بزاوية 0 ـ كع الأفقى) تحت الأنو اع الثلاثة من أنايبب التنقيط باستخدام السر عات الأربات الإبع و المسافتين بين أنابيب التنقيط.

(1) أستاذ القوى والآلات الزراعية ـ كلية الهندسة الزراعية ـ جامعة الأزهر بالقاهرة.

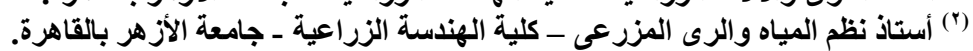

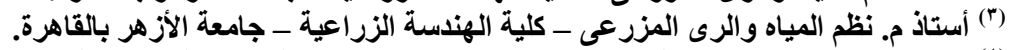

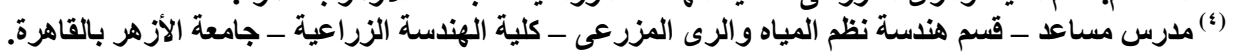

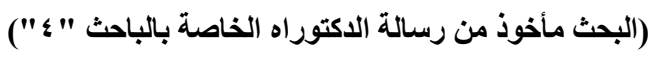


أظهرت النتائج باستخدام التحليل الرياضى أنه يمكن حساب تقدم جبهة البلل في الإتجاهات الثناثة الأفقى و الر أسى و القطرى للتربة الرملية اللومية باستخدام أحد المعادلتين التاليتين:

$$
\begin{array}{r}
\alpha=a . q_{d t}{ }^{c} \\
\text { or } \quad \alpha=b . S^{c}
\end{array}
$$

$$
\text { ( } \alpha
$$

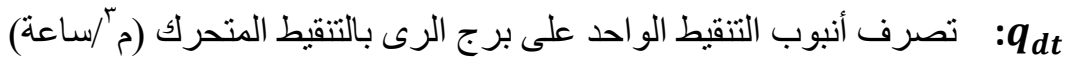

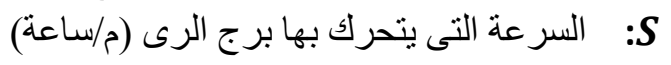

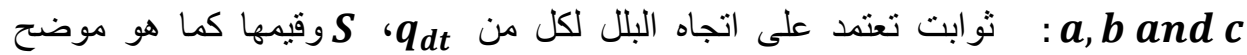

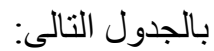

قيم الثوابت a, b, and c المستخدمة في المعادلتين السابقتين مع تصرف أنبوب التتقيط (q)

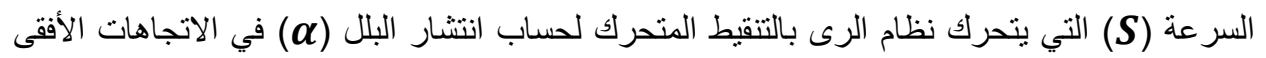
(D)

\begin{tabular}{ccccc}
\hline Wetting & \multicolumn{2}{c}{$\boldsymbol{q}_{\boldsymbol{d t}}$} & \multicolumn{2}{c}{$\boldsymbol{S}$} \\
\cline { 2 - 5 } $\begin{array}{c}\text { direction } \\
{ }^{\prime} \boldsymbol{\alpha} \boldsymbol{c}^{\prime}\end{array}$ & $\boldsymbol{a}$ & $\boldsymbol{b}$ & $\boldsymbol{a}$ & $\boldsymbol{b}$ \\
\hline $\boldsymbol{H}$ & 80.033 & 0.144 & 41.266 & 0.144 \\
$\boldsymbol{V}$ & 76.863 & 0.143 & 40.115 & 0.143 \\
$\boldsymbol{D}$ & 71.541 & 0.094 & 47.196 & 0.094 \\
\hline Mean & $\mathbf{7 6 . 1 4 6}$ & $\mathbf{0 . 1 2 7}$ & $\mathbf{4 2 . 8 5 9}$ & $\mathbf{0 . 1 2 7}$ \\
\hline
\end{tabular}

